\title{
Brief Analysis on the Cultivation Status of College Students' Innovation and Entrepreneurship Ability and Improvement Path
}

\author{
Wensong Li, Renyi Chen, Lei Han*, Shuaiqi Wang \\ School of Electronic Engineering, Tianjin University of Technology and Education, Tianjin 300222, China \\ *Corresponding author. Email: hanleigeneva@163.com
}

\begin{abstract}
This paper analyzes and explores the realistic approach of cultivating college students' innovation and entrepreneurship ability with the existing problems in the cultivation of students in Tianjin colleges and universities as the entry point, in order to provide references for improving the entrepreneurship education and teaching work. Through the current situation of innovation and Entrepreneurship of college students in Tianjin, this paper makes a concrete analysis to find out the problems. From the government level, social level, school level, family level, personal level, it finds out the problems. Then it analyzes the causes of the problems and finds out the improvement methods according to the problems found at all levels. Finally, it explores and implements the methods explain. The ability of innovation and Entrepreneurship of college students is becoming more and more important in our personal and national development. The purpose of this paper is to put forward improvement methods in order to make the ability of innovation and Entrepreneurship of college students reach a new height, and the situation of innovation and entrepreneurship training of college students presents a new picture.
\end{abstract}

Keywords: College students, innovation and entrepreneurship ability, cultivation status, Improvement path

\section{INTRODUCTION}

With the year-on-year increase of college graduates, selfemployment of college students has already become an effective approach of alleviating the social employment pressure. Self-employment of college graduates can alleviate the employment pressure, boost the national and regional economic development, create employment positions and improve the employment rate [1]. In the context of "mass entrepreneurship and innovation", Tianjin government has issued quite a few policies to encourage and support the innovation and entrepreneurship by college students. Besides, colleges and universities also cultivate college students' innovation and entrepreneurship ability in various forms. But in terms of the cultivation status of college students' innovation and entrepreneurship ability in Tianjin, there are still some problems restricting the improvement of cultivation quality.

\section{SIGNIFICANCE OF IMPROVING COLLEGE STUDENTS' INNOVATION AND ENTREPRENEURSHIP ABILITY}

\subsection{Conform to the Trend of International Talents}

Made in China (or Made in PRC) is one of the most recognized tags in the world. But China does not always own the copyrights, since it lacks core technology and popular brands. Featuring low efficiency and low additional value, it is more like vicious price competition. The industrial added value of China's manufacturing industry is only $22.4 \%$ of that of the United States, and $35.43 \%$ of Japan; while the labor productivity of the manufacturing industry is only about $4.38 \%$ of that of the United States, $4.07 \%$ of Japan, and $5.56 \%$ of Germany. Therefore, China's manufacturing industry is now in the low end of global industry value and weak position of low additional value. It shows that attention shall be paid to the innovation and entrepreneurship ability in China, and we should vigorously develop the ability.

As Premier Li Keqiang proposed the view of turning "made in China" to be "created in China", we shall cultivate people's consciousness of creation and spirit of innovation. Contemporary college students shall be pioneers, and as a 
result, the it is especially important for college students to engage in innovation and entrepreneurship. Talents from all walks of life are needed in China, especially those of strong professional ability and high comprehensive quality. The approach of self-employment and innovation makes college students to develop a new thinking mode and lay a solid foundation for the future development.

\subsection{On the Increase of Employment Mode of College Students}

According to the estimation of the Ministry of Education, the number of college graduates reached 7.95 million in 2017, 8.2 million in 2018, and 8.34 million in 2019. From 6.6 million in 2011 to 8.34 million now, it is clear that the competition is really fierce. Besides, the contradiction between the increase of graduates and employment positions would make it more and more difficult for employment, so what should college graduates do?

Currently, the employment pressure is quite severe. Almost dozens of and even hundreds of graduates may compete for one job, and the job may not be satisfactory. This is also the reason why more and more people choose to study abroad or take post-graduate entrance exams. Self-employment is also a way out, suggesting the importance of exercising students' innovation and entrepreneurship ability during the college[2]. Colleges and universities shall cultivate students' entrepreneurship ability, hold activities to improve their practical ability, and enable them to realize their value of life through another way.

\subsection{Improving the Adaptation of Talent Cultivation}

Through four years of study and practice, college students have grasped certain thoughts of innovation and concepts of entrepreneurship, and they also admire successful entrepreneurs and scientific research scholars engaged in innovation. According to the sampling survey data of graduates from some college in Tianjin in 2019, $79 \%$ of them think that entrepreneurship means to make a care, and $64 \%$ of them have the idea of entrepreneurship, suggesting that college students have a clear understanding of the concept, value and significance of entrepreneurship, and some of them have many innovative ideas and projects, and strong desires to do practice.

Everyone will find a place where he fits in. Some college students are suitable for entrepreneurship, and some have distinct innovative thinking. Nowadays, the society is in need of such talents. Colleges and universities hold all kinds of activities for students to communicate their ideas and put forward suggestions, so as to give full play to innovation and entrepreneurship. Contemporary college students refuse to concede defeat. Get their curiosity aroused, so that they can realize their value through efforts, and give full play to their talents [3].

\section{CULTIVATION STATUS OF COLLEGE STUDENTS' INNOVATION AND ENTREPRENEURSHIP ABILITY AND PROBLEM ANALYSIS}

\subsection{Weak Consciousness of Innovation and Entrepreneurship among College Students}

According to the special research on 738 college students and graduate students of different grades from 12 colleges and universities (including higher vocational education) conducted by Tianjin Sub-bureau of National Investigation Bureau, $50.0 \%$ of students would find jobs after graduation, and to be specific, $45.7 \%$ would prepare to work, and the rest $4.3 \%$ would prepare to get self-employed; $17.9 \%$ would prepare to find jobs and take graduate entrance exam; about $30 \%$ would decide to further the study, among which, $24.1 \%$ would choose to take domestic graduate entrance exam.

Due to the impact of traditional educational concepts and growth environment, college students in Tianjin have weak consciousness of innovative thinking and entrepreneurship interest. The cultivation of quality education and innovative thinking is still the short slab of education. Most students are still relatively conservative in terms of future employment choice and life planning. Civil servants and public institutions are still preferred choices. The employment view that "he who excels in learning can be an official" impacts the future life planning of college students subtly. Self-employment is really a reluctant action when no jobs are available, and all these are restricting the cultivation of college students' innovation and entrepreneurship ability in Tianjin.

\subsection{College Students' Level of Such Projects Is Low}

Owing to such reasons as the college (especially undergraduate) curriculum setting and teachers' quality, the knowledge gained by college graduates usually fail to meet the actual social demands, and it is quite common that college graduates get self-employed in different industries. In accordance with Changde sampling survey, $90 \%$ of students choose to start business in service industries, like catering, marketing and agent, thinking that service industries require little investment, little input and low comprehensive quality, and it is easy to enter a profession. But over $80 \%$ have no innovative points.

There college students are restrained by traditional education since a young age. Innovation and entrepreneurship projects declared by college students usually fail to break fixed thinking and lack creativity. Moreover, some just imitate existing foreign or domestic technology and make some adjustments, and accordingly, the projects are lack of technical content. Besides, most projects are related to training agencies, trades or logistics, and there is a lack of innovative projects regarding 
intellectual property and patents. With the technological progress and changes of customer demand, innovation and entrepreneurship projects lack of core competitiveness would certainly be eliminated by the society.

\subsection{College Students' Ability Needs to Be Improved}

It is revealed that the average entrepreneurship success rate of college students across the country is only $5 \%$. The incubation results of project innovation are not satisfactory. $75 \%$ have already been rated as great achievements, and built as key units. As you can imagine, the incubation success rate of other entrepreneurship bases is really worrying.

What's learned from books is superficial after all. College students almost learn about innovation and entrepreneurship from the stories of those entrepreneurs, college classes of innovation and entrepreneurship and career development, entrepreneurship club in college, college competitions like the "Exploration Cup", "Internet +", etc. They are satisfied with a smattering knowledge on the operation mode, marketing mode, fundraising mode of enterprises. Many projects fail since the whole entrepreneur team falls apart due to some difficulties and problems in the initial fundraising construction, operation management and development of customer channels.

\subsection{The Situation of Such Training in Colleges and Universities Needs to be Improved}

The entrepreneurial success rate of college students is only about $5 \%$, and about $20 \%$ of entrepreneurs would be at a loss. The monthly income of about $70 \%$ entrepreneurs is 3,000 Yuan, and only $2 \%$ would exceed 10,000 Yuan. It is clear that colleges and universities are poor at cultivating students' innovation and entrepreneurship ability. Some colleges and universities still focus on the cultivation of talents' professional knowledge, ability and quality, and pay less attention to the cultivation of students' innovation and entrepreneurship ability. There is no a complete curriculum system for the cultivation of students' innovation and entrepreneurship ability. Many colleges and universities just set a class to teach the theoretical knowledge of innovation and entrepreneurship, and hold related entrepreneurial competitions and expert lectures, lack of practical links. Some colleges and universities are lack of professional teaching staff for the cultivation of students' innovation and entrepreneurship ability. Besides, innovation and entrepreneurship courses are given by teachers of other professions, which greatly reduces the teaching quality and effect of innovation and entrepreneurship courses.

\subsection{Inadequate Implementation at the Government Level}

According to the following figure, it is clear that government gives little support to the entrepreneurship, which fails to help college students to start the business. As a result, college students have to get support from their families or credit loans, which makes them give up innovation and entrepreneurship, and turn to other ways. Accordingly, the number of innovation and entrepreneurship students decreases, and it also prevents college students from giving full play to their gift and ability.

Policy support issued by the government mainly concentrates on launching venture competitions, subsidizing entrepreneurship, and constructing incubators, etc. It remains to be improved in the cultivation of college entrepreneurs' professional knowledge. In recent years, in the context of mass entrepreneurship and innovation, Tianjin government also responds to the call of central policy, adheres to the principles of government guidance, market guidance and demand guidance, and issues some related policies. But it is still less perfect in the implementation of some education policies regarding the innovation and entrepreneurship. In addition, some auxiliary policies supporting the innovation and entrepreneurship have been issued, but it is still of little help for college students confronting the great market pressure and economic issues, and some students even give up the development opportunities of innovation and entrepreneurship.

Table 1 Proportion of innovative and Innovative Fund sources for college students

\begin{tabular}{|c|r|}
\hline bank lending & $6 \%$ \\
\hline venture investment & $2 \%$ \\
\hline government research entrepreneurship fund or preferential loan & $1 \%$ \\
\hline investment or loan of relatives and friends & $65 \%$ \\
\hline personal savings & $15 \%$ \\
\hline others & $11 \%$ \\
\hline
\end{tabular}




\section{CULTIVATION AND PROMOTION PATH}

\subsection{Optimizing the Environment at the Government Level}

It is clear from the following figure that the government assistance in the optimization of innovation and entrepreneurship environment for students is less satisfactory. But we have to believe that great government efforts would receive satisfactory results. In terms of Internet + project, in 2019, 38,400 projects from 118 colleges and universities affiliated to the ministry, and 932 local colleges and universities have been approved, involving 161,000 students and 590 million Yuan of project fund, which effectively improve students' ability of practicing innovation and entrepreneurship. Other countries also make certain achievements after laying emphasize on projects. Therefore, when the government makes more efforts to optimize the innovation and entrepreneurship environment, it will certainly further improve college students' innovation and entrepreneurship level.

As stated above, Tianjin government shall accelerate college students' innovation and entrepreneurship educational reform comprehensively, improve the incentive policies for innovation and entrepreneurship, publicize policies, and optimize students' innovation and entrepreneurship environment. It can set venture street in places where colleges and universities gather. After the government issues related innovation and entrepreneurship policies, specially-assigned persons can propagandize in colleges and universities and answer questions, so as to implement policies. They can encourage excellent college entrepreneurs, and affirm their contribution to the society. The government shall also promote university-industry cooperation, and smoothen students' internship channels, so that students with the ideas of entrepreneurship or internship can enter practical environment and learn about how enterprises work and develop, so as to get prepared for future entrepreneurship and gain profound knowledge.

\subsection{Strengthen Training in Schools}

In the 1980s, Carter administration opened the door to innovation and entrepreneurship in the United States. Today, innovation and entrepreneurship has already been normal in the United States. China's entrepreneurial experts explain that innovation and entrepreneurship education is offered as a general education course in American colleges, and $80 \%$ to $90 \%$ college students would participate in innovation and entrepreneurship. Statistics show that about $90 \%$ of the social wealth in the United States is gained after the 1980s, proving the tremendous impetus of innovation and entrepreneurship. All achievements are obtained on the basis of an essential element, namely the attention to and cultivation of college students' innovation and entrepreneurship ability form the school level. Therefore, we shall learn from this method, and strengthen the cultivation of college students' innovation and entrepreneurship ability from the school level.

In conclusion, schools shall cultivate students' concept of innovation and entrepreneurship actively, guide students to set up a positive and optimistic attitude, reinforce the combination of theoretical and practical teaching of innovation and entrepreneurship, improve the pertinence of innovation and entrepreneurship education, enhance the construction of teaching staff of innovation and entrepreneurship, offer diversified courses, and strengthen the innovation and entrepreneurship education for college students. Besides, it can set innovation and entrepreneurship incubation bases, to provide a good environment for the innovation and entrepreneurship by college students, launch competitions actively, inspire college students' innovation and entrepreneurship thinking, and enhance their innovation and entrepreneurship ability.

\subsection{Support Students from the Family Level}

Above all, family members shall abandon the traditional conservative thoughts and official standard thoughts, and support the innovation and entrepreneurship action if financially allowed. Substantial studies have shown that different growth environments, different jobs of parents and personalities, education ways would impact the individual intention of innovation and entrepreneurship, and the impact is great. Scholars have pointed out that family members' support to entrepreneurial behavior is in a positive correlation with the entrepreneurship intention. Family members can provide financial support and interpersonal network to entrepreneurs, and family background impacts children's outlook on life, values and the world, attitude and behaviors subtly.

\subsection{Personal Transformation}

According to statistics, about $70 \%$ college students in the United States have entrepreneurial intention. Only 20\% start business actually after graduation; but $80 \%$ college students in China have entrepreneurial intention. Only $0.02 \%$ practice it actually after graduation. We may wonder why some give up. Because we are lack of innovation and entrepreneurship ability, and less confident. We would always think of failure. Therefore, to improve the ratio of entrepreneurship, as well as the confidence and ability of college students, it is critical to cultivate students entrepreneurial intention [4].

The optimization of innovation and entrepreneurship environment for college students by governments and schools provides a basis for the success of innovation and entrepreneurship, but confidence, ability and entrepreneurship intention of of college students are key factors deciding the entrepreneurial success. Nowadays, 
despite of the great competitive pressure, a widespread mood that "employment is more stable than selfemployment" has developed, and we are lack of the spirit of challenging ourselves and the present situation, or the confidence to face and conquer problems. Therefore, college students shall change employment ideas, try to enrich themselves with professional knowledge, seize all kinds of opportunities to exercise, enrich the practical entrepreneurship experience, improve the quality comprehensively and get prepared to achieve success [5].

\section{SUMMARY}

College students are the major force of innovation-oriented country and economic construction, and the quality of innovation and entrepreneurship cultivation is crucial for the success of future society. The government shall optimize the innovation and entrepreneurship environment; schools shall strengthen the cultivation of students' innovation and entrepreneurship ability; and families shall support students' innovation and entrepreneurship; students themselves shall change employment ideas and enhance their innovation and entrepreneurship ability and confidence.

To follow the international trend and meet international talent standards, we shall pay attention to college students' innovation and entrepreneurship ability. Thanks to the severe employment situation, it is beneficial to cultivate college students' innovation and entrepreneurship ability from the perspective of disposition cultivation. In front of existing problems in innovation and entrepreneurship ability, we shall solve the problems, so as to better cultivate students' innovation and entrepreneurship ability. Finally, it is hoped that the above improvement measures can get certain results in the cultivation college students' innovation and entrepreneurship ability.

\section{REFERENCES}

[1] Hao Jiaxiang, Study on the Improvement Path of College Students' Self-Employment Ability in the Context of Mass Innovation and Entrepreneurship [J]. Education Modernization, 2018, 5 (50): 76-78.

[2] Wang Linna, Study on the Cultivation of College Students' Innovation and Entrepreneurship Ability and Improvement path - A Case Study on Yunnan Normal University [J]. Industrial \& Science Tribune, 2018, 17 (18): 283-284.

[3] Lei Zhenxiang, Yang Liu, On the Cultivation of College Students' Entrepreneurship Ability: Significance, Dilemma and Implementation Path [J]. Journal of Yangzhou University (Higher Education Study Edition), 2017 (1): 45-49.

[4] When the history that U.S. Government promoted the transfer of university technology started - Based on the sorting and observation of the book Creating the Market University: How Academic Research Become an Economic Engine

[5] Jin Jin, Li Yaokuang, Research on Model of Entrepreneurship for Engineering College Students [J]. Journal of Hefei University of Technology (Social Sciences), October 2010. 